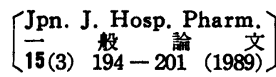

\title{
ラットにおけるアテノロールの滕管吸収
}

\author{
田部和久 ${ }^{* 1}$, 宮地紀子*2, 多々良紀子*2, 伊藤壮一*2, 山崎 勝*2 \\ 大阪大学医学部附属病院薬剂部*1 \\ 大阪大学薬学部薬剤学教室*2
}

\section{Intestinal Absorption of Atenolol in Rat}

\author{
KAZUHISA TANABE*1, NORIKO MIYAJI*2, NORIKO TATARA*2, \\ SOICHI ITOH ${ }^{* 2}$, and MASARU YAMAZAKI*2 \\ Department of Pharmacy, Osaka University Hospital*1 \\ Faculty of Pharmaceutical Sciences, Osaka University*2
}

(Received January 5, 1989)

\begin{abstract}
Intestinal absorption characteristics of atenolol (AT) were measured by the plasma concentrations after oral and small intestinal administrations and monitoring its disappearance from in situ intestinal loops in anesthetized rat. Relative AUC of AT after oral administration in rat was $24 \%$ as compared to AUC value of intravenous administration. However, relative AUC for small intestinal administration in the anesthetized rat was $76 \%$. Following administration of AT into duodenal, jejunal and ileal loops, AUC calculated from blood levels was 705, 613, and $838 \mu \mathrm{g} \bullet \mathrm{min} / \mathrm{ml}$, respectively, and the order was consistent with the absorption rate.

Disappearance rate constants were $0.3-0.5 \mathrm{~h}^{-1}$. The result shows that there is no difference in absorption from each segment of intestine. Rat intestinal AT transport showed concentration dependency, especially up to $25 \mu \mathrm{g} / \mathrm{ml}$ in the mucosal medium, in an experiment using in vitro everted rat intestinal sac prepared from duodenum, jejunum and ileum.
\end{abstract}

Keywords_atenolol; intestinal absorption; in situ loop method; bioavailability; in vitro everted sac method; rat

\section{は じめに}

アテノロール (以下, AT) は心蔵の 交感神経 $\beta$ 受容 体に対する選択的逗断薬であり，本態性高血圧，狭心 症, 頻脈性不整脈に対して有効性が認められ ${ }^{1,2)}$, 臨床上 汎用されている. AT はプロプラノロールやオキシプレ

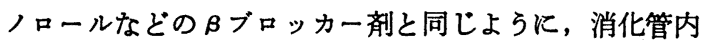
の $\mathrm{pH}$ 域ではほとんどイオン型として存在するが, 油水 分配率は小さく親水性である.

一般に，薬物の消化管吸収はその物理化学的性質に支

*1 大阪市福島区福島 1-1-50；1-1-50, Fukushima, Fukushima-ku, Osaka-shi, 553 Japan

*2 吹田市山田丘 1-6;1-6, Yamadaoka, Suita-shi, Osaka, 565 Japan
配されることが多く，さらに溶液中ではイオン化率にも 大きな影響を受ける. しかし水溶性のサリチル酸誘導 体3)や及ラクタム系抗生物質 ${ }^{4)}$ などの消化管吸収は必ず しも $\mathrm{pH}$ 分配説や単純払散のみでは説明できないことが 報告されている. 水溶性の AT は, 犬に扎ける腸管ルー プ法において, solvent drag または能動輸送機構で吸 収されている可能性があると報告されている5)。そこで 今回は AT の消化管吸収における生体内利用率, および 吸収部位について検討し, 吸収機構についても考察を行 ったので報告する。

\section{实俨 の 部}

1. 試 料

AT はアイ・シー・アイファーマ侏より提供をらけ 
た.フェノバルビタールは局方品を用い，その他実験に 使用した試薬はすべて特級試薬を供した。

\section{2. ラットにおける吸収实点}

Wistar 系雄性ラット（体重 215 250 g ）を用い, 実 験前24時間絶食した.

1）静脈内投与.

ペントバルビタール麻酔下 $(40 \mathrm{mg} / \mathrm{kg}$, i.p.) 頙静脈 と大䬶動脈内にポリェチレン製カニューレ $(0.6 \mathrm{~mm}$, o.d.) を挿入した．AT 生理食塩液 $(10 \mathrm{mg} / \mathrm{ml})$ を調製 し, 頚静脈内カニューレを介して 1 分間かけて注入し た. 採血は大酿動脈カニューレから経時的に 5 時間まで 行った. 血液はただらに $3000 \mathrm{rpm}$ で 5 分間遠心分離し て血漿をえた．投与量は $20 \mathrm{mg} / \mathrm{kg}$ で行った.

2）経口投与

エーテル麻酔下, 大眼動脈内にカニューレを施し, ボ ールマンケージに移して最低 2 時間放固した。麻酔から 完全に覚醒したのを確認したのち，胃ゾンデを用いて $\mathrm{AT}$ 水溶液 ( $1 \mathrm{mg} / \mathrm{ml})$ を投与した. 採血は静脈投与時 と同様に行った.

3）小腸内投与

麻酔した場合 (ペントバルビタール麻酔) は, 腹部正 中線にそって開腹し，幽門部から AT 水溶液 $(10 \mathrm{mg} / \mathrm{ml})$ をシリンジで注入したのち，注入部位のすぐ下部を結禁 した. 採血は大眼動脈内カニューレより行った. 一方, 非麻酔においては，エーテル麻酔下シリコン製カニュー レ（1 mm，o.d.）を胃壁を介して十二指腸内に留置し， 腹壁を縫合したのちボールマンケージに移し，以下経口 投与時と同様に行った.

\section{3. 家鬼における吸収英硂}

白色雄性家鬼（体重2.6 3.3kg）を使用し，実験前一 晚絶食し, 水は自由に与えた. 経口投与の場合, 䨢食に よる胃内容物の残留を防止するため, 頚かせを施して絶 食を行った．投与量は $30 \mathrm{mg} /$ body とした. 採血は耳介 静脈から程時的に 5 時間まで行い, $3000 \mathrm{rpm}$ で 5 分間遠 心分離して血漿をえた。

1）静脈内投与

AT 生理食塩液 $2 \mathrm{ml}$ を家鬼の左耳介静脈から投与し た. 投与後右耳介静脈から血液を採取した。

2) 経口投与

$\mathrm{AT}$ 水溶液 $4 \mathrm{ml}$ を, 経ロ用ゾンデを用いて投与した.

\section{4. in situ ループ法}

Wistar 系雄性ラット（体重 160～250 g ）を一晚絶食 後, ペントバルビタール麻酔下腹部正中線にそって開腹 した.十二指腸としては胃幽門部の下向 $2 \mathrm{~cm}$ から $10 \mathrm{~cm}$, 空腸としては幽門部の下向 $20 \mathrm{~cm}$ から $10 \mathrm{~cm}$, 回腸とし
ては回盲部の上向 $5 \mathrm{~cm}$ から $10 \mathrm{~cm}$ をそれぞれ用い，各 部位に $5 \mathrm{~cm}$ のループを作った.な担管は実験中結奖 した。濃度が $0.05 \%$ と $0.5 \%$ の AT 生理食塩液 $0.5 \mathrm{ml}$ を 各ループの上端から注入した. $10,30,60$ 分後にループ を切出し, ループ内液を $0.01 \mathrm{~N} \mathrm{HCl} 5 \mathrm{ml}$ で洗い出し, 回収液は $10 \mathrm{ml}$ とした. またループの 組織は約 $100 \mathrm{mg}$ を切取り，精製水 $2 \mathrm{ml}$ を加えてホモジナイズした。こ の組織抽出液および回収液中の ATを HPLC 法により 定量し，それぞれに残存している薬物量を算出した.

吸収率の計算は式(1)から求めた。

$$
\text { 吸収率 }=\left(\mathrm{C}_{\mathrm{I}}-\mathrm{C}_{\mathrm{L}}-\mathrm{C}_{\mathrm{T}}\right) / \mathrm{C}_{\mathrm{I}}
$$

なお $\mathrm{C}_{\mathrm{I}}$ は注入薬物量, $\mathrm{C}_{\mathrm{L}}$ はループ内残存量, $\mathrm{C}_{\mathrm{T}}$ は 組織蓄積量である.

ループ内投与後の血中濃度の測定は, ペントバルビタ 一ル麻酔下で大腿動脈にカニューレを施したのち, いず れかの部位に一つのループを作り，0.5\% AT 生理食塩 液 $0.5 \mathrm{ml}$ を注入した. 経時的にカニューレから採血し, 遠心分離によりえた血漿について HPLC 法によりATを 測定し，その濃度を算出した。

\section{5. in vitro 摘出反轱腈筒法}

Wistar 系雄性ラット（体重 185～250 g ）を一晚絶食 し，ペントバルビタール麻酔下腹部正中線にそって開腹 した. 幽門部から回盲部までの腸管を切出し, Barrらの) の方法で行った．反転腸管内には Krebs-Ringer 炭酸緩 衝液（pH 7.4） 0.5ml を注入した. ATを含む同一緩衝 液 $50 \mathrm{ml}$ の入った三角フラスコを $37 \pm 0.5^{\circ} \mathrm{C}$ または $4 \pm$ $0.5^{\circ} \mathrm{C}$ に保ち，95\% $\mathrm{O}_{2}$ と $5 \% \mathrm{CO}_{2}$ を含むガスを吹込 みつつ，この中に反転腸管を入れて緩やかに振とうし

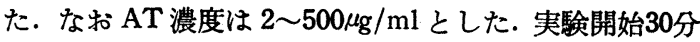
後に反転腸管を取出し, 切開いて内容液 (漿膜側) を取 り $0.01 \mathrm{~N} \mathrm{HCl}$ で洗浄して $5 \mathrm{ml}$ とした. また粘膜側の 溶液をも採取した．獎膜側および粘膜側の溶液から AT を抽出し，HPLC 法によりAT量を測定した. 重量から 墏膜側への移行量 (Clearance, CL) を次式に従って補 正した.

$$
\mathrm{CL}\left(\mathrm{ml} \cdot \mathrm{h}^{-1} \cdot \mathrm{g}^{-1} \text { tissue }\right)=\frac{\text { 獎膜側のA T 量 }}{\mathrm{A} \mathrm{T} \text { 初濃度・時間・組織重量 }}
$$

\section{AT の定是}

AT の定量は HPLC 法により行った. 血液の場合, 血 衤 $0.2 \mathrm{ml}$ に $1 \mathrm{~N} \mathrm{NaOH} 0.2 \mathrm{ml}$ とクロロホルム $7 \mathrm{ml}$ を加 えて10分間振とうした. $2000 \mathrm{rpm} て ゙ 5$ 分間遠心分離後, クロロホルム層 $6 \mathrm{ml}$ を別の試験管に取り, 減圧乾固し た.これに内標準としてフェノバルビタール $4 \mu \mathrm{g} / \mathrm{ml}$ を 含む移動相 $80 \mu 1$ を加えて溶解し，その $60 \mu 1$ を HPLCに 注入した. 血液以外の試料も希釈後 $0.2 \mathrm{ml}$ を取り, 同 
様の操作で抽出した. ポンブは JASCO TRI ROTAR-II (日本分光), 検出器は JASCO UVITEC 100-III（日 本分光）を用い，波長は $224 \mathrm{~nm}$ とした。 カラム（150× 4 i.d. mm) はワコーゲル ODS-5K（和光純薬）を充填 したものを使用した。移動相は $10 \mathrm{mM}$ リン酸緩衝液 (pH 5.0, $2 \mathrm{mM}$ オクタンスルホン酸ナトリウム含有): アセトニトリル $=80: 20(\mathrm{v} / \mathrm{v} \%)$ を用い,流速は $1.2 \mathrm{ml} /$ $\mathrm{min}$ とした. 定量限界は $100 \mathrm{ng} / \mathrm{ml}$ であった.

\section{結果および考洜}

\section{1. ラットにおける生体内利用率}

水溶性薬物は一般消化管からは吸収され難く，バイ オアベイラビリティも低いことが多い，AT の $\mathrm{pKa}$ は 9.75 であり7)，消化管の $\mathrm{pH}$ 域ではほとんどイオン化し た状態で，親水性を示す．そこで，ATを経口および小 腸内に直接投与し，吸収量について検討した．Fig.1は 5 時間までの血將中濃度曲線を示す。

$\mathrm{AT}$ 水溶液を経口投与した場合, 血墏中濃度の上昇は 緩やかで， 2 時間後に最高值 $2.0 \mu \mathrm{g} / \mathrm{ml}$ を示した．麻酔 下の小腸内に投与した場合には，投与 1.5 時間後に最高 血漿中濃度は $5.9 \mu \mathrm{g} / \mathrm{ml}$ となった，その後の消失も遅 く, 5 時間後でも $2.4 \mu \mathrm{g} / \mathrm{ml}$ と高く, 吸収が持続してい ることが示唆された。この小腸内投与のピーク值は経口 投与時の值に比べて約 3 倍になり， 1 時間以後 5 時間ま での血墏中濃度は有意汇高い值を示した $(p<0.05)$. 経

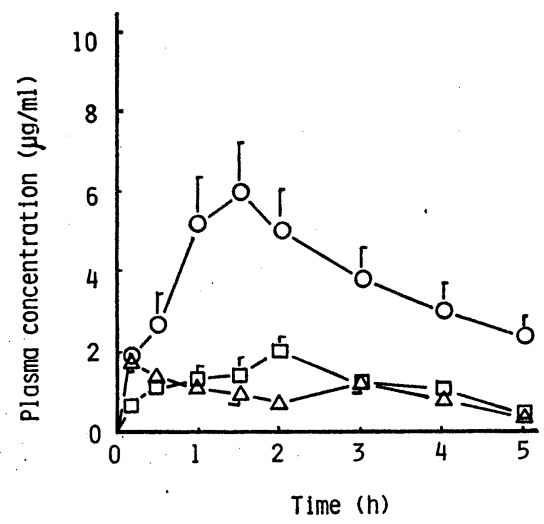

Fig. 1. Plasma Concentrations of Atenolol after Oral and Small Intestinal Administrations in Rats $\square$ : Oral, $\bigcirc$ : small intestine (anesthetized), $\triangle:$ small intestine (conscious).

Each point represents the mean \pm S. E. of five rats.
口投与は非麻醉下であったので，同じ条件で小腸内に直 接投与した．このときのピークは投与 10 分後に $1.8 \mu \mathrm{g} /$ $\mathrm{ml}$ となり，2時間まで緩やかに消失するが，3時間後 飞は再び血洯中濐度は上昇し，吸収は持続していること がわかった．このように経口投与と類似したパターンを 示すことから，麻酥下の小腸投与における吸収量の增大 は，麻酔により小腸の固有運動が影響を受け，腸管内の 薬物移行速度が減少したことが要因になっていると考え られる。

次に AT 水溶液を静脈内に投与し，経口投与したとき の生体内利用率について比較を行った．Fig. 2 は静脈 内投与したときの 5 時間までの血墏中濃度曲線を示す.

健常人の静脈内投与では血繁中濃度の変化は 3-ュン パートメントモデルに従う8) と報告されている。そこで Fig. 2 の血墏中港度の減少を 3 相と仮定 し，3-コンパ ートメントモデルに基づき，山岡”の MULTI で解析し た. 各相の半減期は, $\alpha$ 相が 1.3 分, $\beta$ 相が11分, $\gamma$ 相 が 116 分であった.

経口および小腸内投与したときの血漿中濃度から， $\mathrm{T}_{\max }, \mathrm{C}_{\max }$ および 5 時閪までの AUCを算出し，静 脈内投与による AUCを100\%としたときの相対利用率 を求めた．結果を Table 1 亿示す． $\mathrm{T}_{\max }$ では非麻醁 下の小腸投与以外はいずれる 1 時間以上で，経口投与で は 2 時間以上であった．経口投与の $\mathrm{C}_{\max }$ は，非麻醉下 の小腸投与の值に比べてやや高く，AUC に执いても大 きい値を示したが，いずれる有意差は認められなかっ

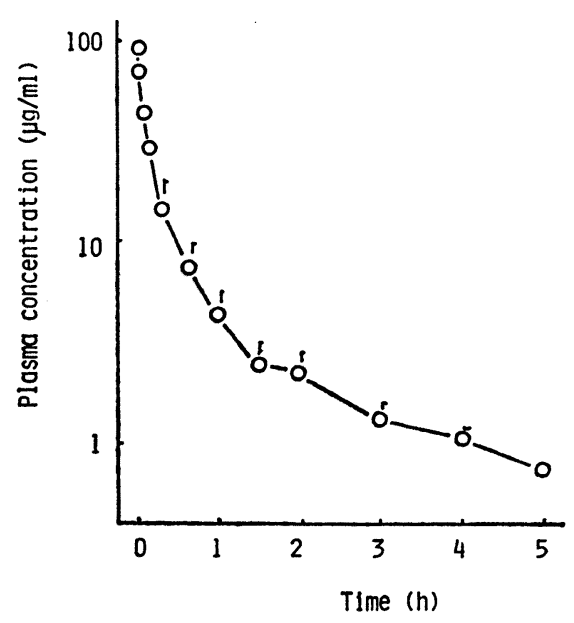

Fig. 2. Plasma Concentration of Atenolol after Intravenous Administration in Rats

Each point represents the mean \pm S.E. of five rats. 
Table 1. Pharmacokinetic Parameters of Atenolol after Intravenous, Oral, and Small Intestinal Administrations in Rats

\begin{tabular}{|c|c|c|c|c|}
\hline Route & $\begin{array}{l}T \max \\
(\min )\end{array}$ & $\begin{array}{l}\text { Cmax } \\
(\mu \mathrm{g} / \mathrm{m} 1)\end{array}$ & $\begin{array}{l}\text { AUC } \\
(\mu \mathrm{g} \cdot \min / \mathrm{m} l)\end{array}$ & $\begin{array}{l}\text { Relative } \\
\text { AUC (\%) }\end{array}$ \\
\hline Intravenous & & . & $1501.2 \pm 242.6$ & 100 \\
\hline Oral & $138.0 \pm 26.2$ & $2.2 \pm 0.2$ & $366.1 \pm 29.3$ & 24 \\
\hline $\begin{array}{l}\text { Small intestine } \\
\text { (anesthetized) }\end{array}$ & $96.0 \pm 6.0$ & $6.1 \pm 1.2$ & $1141.9 \pm 210.3$ & 76 \\
\hline $\begin{array}{l}\text { Small intestine } \\
\text { (conscious) }\end{array}$ & $18.0 \pm 4.9$ & $1.8 \pm 0.2$ & $274.7 \pm 21.4$ & 18 \\
\hline
\end{tabular}

Results represent the mean $\pm S . E$. of five rats.
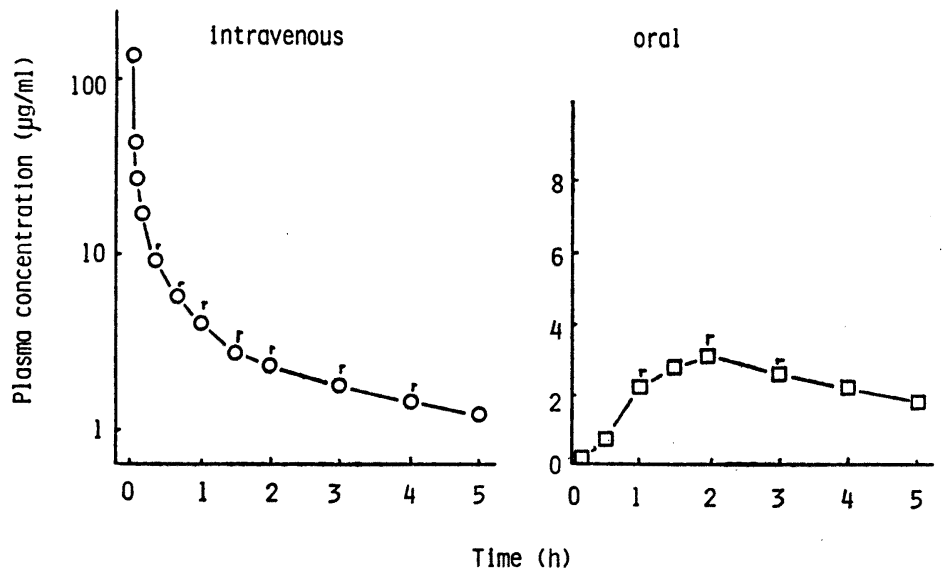

Fig. 3. Plasma Concentrations of Atenolol after Intravenous and Oral Administrations in Rabbits

Each point represents the mean \pm S.E. of five rabbits.

た。しかし経口投与と麻酔下投与との $\mathrm{C}_{\max }$ や AUC の 間には，ともに有意差 $(\mathrm{p}<0.01)$ が認められた。 ラッ トの経口投与では相対利用率が $24 \%$ であった．今回のよ らに麻䣲による生理的条件の変化が, 小腸内投与のバイ オアペイラビリティに大きな影䇾を及ぼすことは，今後 の吸収実験を行うらえで十分に注意する必要があるとい える。

\section{2. 家息における生体内利用率}

ラットにおける経口投与では, 麻酔の有無により生体 内利用率は大きく変化した．そこで非麻酔の条件下で投 与できる家鬼に, 静脈内および経口投与したときの血中
濃度について検討を行った．Fig. 3 は静脈内および経 ロに投与したときの ATの 5 時間までの血漿中濃度曲線 を示す。

静脈内投与の場 合は, ラットと同様に 3-ュンパート メントモデルにより MULTI9) で解析した. 各相の半減 期は， $\propto$ 相が1.9分， $\beta$ 相が21分， $\gamma$ 相が 171 分となり， ラットよりやや長くなったが，類似した消失パターンを 示した。経口投与では, 血墏中濃度のピークは投与 2 時 間後に $3.1 \mu \mathrm{g} / \mathrm{ml}$ となり，5時間後でも $1.7 \mu \mathrm{g} / \mathrm{ml}$ と高 い濃度を維持していた。 この值は静脈内投与とほぼ同じ で, 消失が遅いことから, 吸収は長時間持続しているこ 
Table 2. Pharmacokinetic Parameters of Atenolol after

Intravenous and Oral Administrations in Rabbits

\begin{tabular}{llllc}
\hline \hline Route & $\begin{array}{l}\text { Tmax } \\
(\min )\end{array}$ & $\begin{array}{l}\text { Cmax } \\
(\mu \mathrm{g} / \mathrm{m} 1)\end{array}$ & $\begin{array}{c}\text { AUC } \\
(\mu \mathrm{g} \cdot \mathrm{m} \min / \mathrm{m} 1)\end{array}$ & $\begin{array}{c}\text { Relative } \\
\text { AUC }(\%)\end{array}$ \\
\hline Intravenous & & & $1370.8 \pm 215.8$ & 100 \\
Oral & $138.0 \pm 18.0$ & $3.3 \pm 0.5$ & $635.4 \pm 54.7$ & 46 \\
\hline
\end{tabular}

Results represent the mean $\pm S . E$. of five rabbits:

とが示唆された。

次に経口投与に怙ける吸収パラメータを算出し, 静脈 内投与による AUC から相対利用率を求めた。結果を Table 2 に示す.

経口投与における $\mathrm{T}_{\max }$ はラットの場合と同じように 2 時間以上であった. 相対利用率は約 $46 \%$ であり, ラッ トの場合の約 1.9 倍に増大した.

以上の結果から, 経口投与による AT の生体内利用率 はラットおよび家鬼とも50\%以下であるが，吸収はかな り持続していることが明らかとなった。

\section{AT の消化简吸収部位}

ラットの十二指腸, 空腸, および回腸部位にループを 形成し, $0.5 \% \mathrm{AT}$ 生理食塩液を注入し, 吸収におよほ す部位の影響について血獎中濃度から検討を行った。

Fig. 4 は各部位に投与後, 5 時間までの血漿中濃度の 推移を示す.

十二指腸, 空腸, 回腸のいずれの部位においても血漿 中濃度のピークは 2 時間後に認められ, その濃度はそれ ぞれ 3.6, 2.8, $4.5 \mu \mathrm{g} / \mathrm{ml}$ であった. 十二指腸と空腸の 血獎中濃度は非常に類似した推移を示した. しかし回腸 の場合には，他の部位に比べてかなり吸収速度が速く， 特に投与30分後と 1 時間後の血墏中濃度は高い值となっ た.これは回腸部位の $\mathrm{pH}$ が他の部位に比べて高く, AT の $\mathrm{pKa}$ が 9.75 であることから, 注入した初期では非イ オン型の薬物量が多く, 一時的に吸収が増大したことが 考えられる. 十二指腸, 空腸, 回腸投与の血漿中濃度か ら求めた 5 時間までの AUC は，それぞれ 705, 613, 838 $\mu \mathrm{g} \cdot \mathrm{min} / \mathrm{ml}$ であった.

次に 5 時間後のループ内の AT 残存量と組織内取込み 量から, 吸収率を式(1)から求めた。各部位の吸収率は十 二指腸が $86 \%$, 空腸が75\%, 回腸が $97 \%$ であり, Fig. 4 の血奬中濃度から求めた AUC の順序と一致した.

十二指腸, 空腸, 回腸における吸収率が異なったの

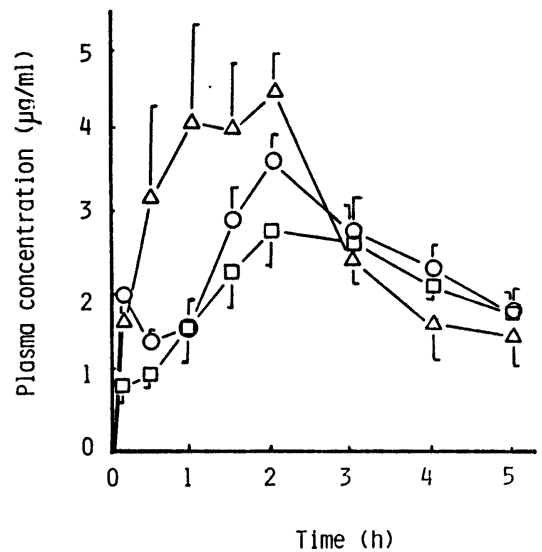

Fig. 4. Plasma Concentrations of Atenolol after Administration into Each Loop of Rat Small Intestine

$\mathrm{O}$ : Duodenum, $\square$ : jejunum, $\triangle$ : ileum.

Each point represents the mean \pm S. E. of five rats.

で, 各部位の消失速度定数を求めた．各ループ内に $0.5 \%$ AT 生理食塩液を注入し，ループ内の AT 残存量の対数 と時間との関係を求めた (Fig. 5).

良好な直線関係がえられ，ループ内からの ATの消失 は一次速度式に従うことが明らかとなった。この直線の 傾きから求めた各部位の消失速 度定数は, 十二指腸が $0.42 \mathrm{~h}^{-1}$, 空腸が $0.30 \mathrm{~h}^{-1}$, 回腸が $0.53 \mathrm{~h}^{-1}$ で, 吸収率

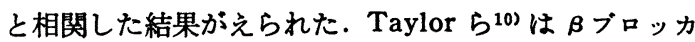
一剂の吸収部位の影霍を in situ ループ法で検討してい る. $0.5 \mathrm{mg} / \mathrm{ml}$ のAT投与では, 空腸と回腸の消失速度 定数はいずれる $0.3 \sim 0.4 \mathrm{~h}^{-1}$ であり，今回の結果はほ ぼ同じ值であった。

Fig. 1 の経口投与の血漿中鋠度曲線から求めた吸収 速度定数は $0.45 \mathrm{~h}^{-1}$ であり, ループ法での 速度定数に 
近い値であった。したがって，in situ ループ法による 各部位からの吸収率は，経口投与したときの吸収傾向を 反映しているるのと思われる。また $0.05 \%$ AT 生理食 塩液を注入したときも一次式徥って消失し，速度定数 は十二指腸が $0.35 \mathrm{~h}^{-1}$, 空腸が $0.57 \mathrm{~h}^{-1}$, 回腸が $0.80 \mathrm{~h}^{-1}$ となり，0.5\% 液を投与のときと同じ傾向が得られた。

以上の結果から，消化管からの吸収部位は回腸部位が 最も良好であるが，十二指腸や空腸に比べても大きな差 とはならず，小腸全体から吸収されているといえる。 たATの投与量が $0.05 \%$ と $0.5 \%$ とでは，各部位の消失 速度定数にあまり差がなかったことから，この濃度範囲 では受動拡散で吸収されていると推察することができ ろ.

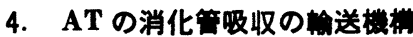

In vitro 反転腸管法において，AT の取込み量に及ほ す温度の影響を検討した。 十二指腸, 空腸, および回腸 部位の粘膜側の AT 濃度を $5 \mu \mathrm{g} / \mathrm{ml}$ とし, 繁膜側と粘膜 側との薬物濃度比 (S/M 比)を $37^{\circ} \mathrm{C}$ と $4^{\circ} \mathrm{C}$ で求めた。

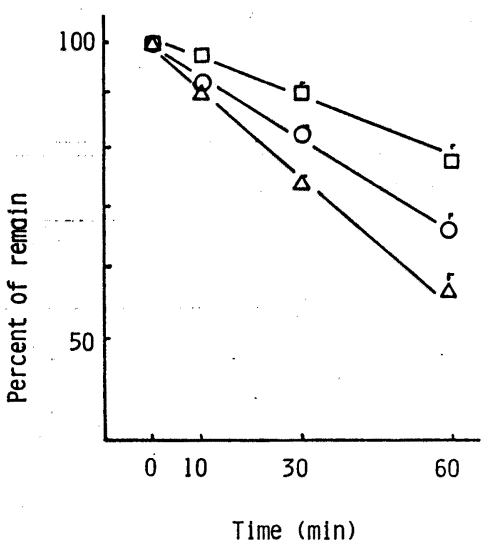

Fig. 5. Disappearance Time Courses for Atenolol from Each Loop of Rat Small Intestine Key : see Fig. 4.

Each point represents the mean \pm S.E. of three rats.

Table 3. Effect of Temperature on Serosal to Mucosal Concentration Ratio of Atenolol across the Everted Rat Intestinal Sacs

\begin{tabular}{lcc}
\hline & \multicolumn{2}{c}{ S/M ratio ${ }^{2)}$} \\
\hline & $37^{\circ} \mathrm{C}$ & $4^{\circ} \mathrm{C}$ \\
Duodenum & $0.86 \pm 0.02$ & $0.48 \pm 0.01$ \\
Jejunum & $0.66 \pm 0.07$ & $0.57 \pm 0.10$ \\
Ileum & $0.80 \pm 0.16$ & $0.63 \pm 0.03$ \\
\hline
\end{tabular}

a) Serosal to mucosal concentration ratio of atenolol.

The initial concentration in mucosal fluid was $5 \mu \mathrm{g} / \mathrm{ml}$.

Results represent the mean \pm S.E. $(n \geqq 3)$.

結果を Table 3 に示す.

いずれの部位とす S/M 比は 1 以下であり， $37^{\circ} \mathrm{C}$ から $4^{\circ} \mathrm{C}$ にすることにより $\mathrm{S} / \mathrm{M}$ 比は小さくなった.この濃 度ではATは単純な受動輸送ではなく,何らかの carrier により輸送されていることを示唆する結果であった.

次に $37^{\circ} \mathrm{C}$ に打いて AT 濃度を $2 \sim 500 \mu \mathrm{g} / \mathrm{ml}(7.5 \sim$ $1880 \mu \mathrm{M})$ まで変化させて， S/M 比および CL への影響 を検討した. AT 濃度による S/M 比の变化を Table 4 に, CL の変化を Fig. 6 に示す.
十二指腸，空腸，回腸における $\mathrm{S} / \mathrm{M}$ 比は，いずれの 濃度においても 1 以下であったことから，少なくともこ れらの濃度ではATの吸収に能動輸送が関与している可 能性は薄いと考えられる．Fig. 6 亿执いて CL-AT 濃 度曲線は 2 相性の関係を示した。すなわち，CL は AT の濃度が増加するにしたがって減少し, $25 \mu \mathrm{g} / \mathrm{ml}(94 \mu \mathrm{M})$ 以上で AT 濃度に関係なく注ほ定の值を示した。

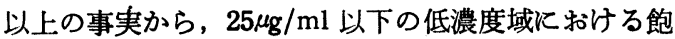
和可能な吸收過程と, それ以上の濃度域における不飽和 
Table 4. Effect of Initial Concentration in Mucosal Fluids on Serosal to Mucosal Concentration Ratio of Atenolol across the Everted Rat Intestinal Sacs

\begin{tabular}{cccc}
\hline \hline \multirow{2}{*}{$\begin{array}{c}\text { Soncn. } \\
(\mu \mathrm{M})\end{array}$} & Suodenum & Jejunum & Ileum \\
\cline { 2 - 4 } & & & \\
\hline 7.5 & $0.57 \pm 0.04$ & $0.81 \pm 0.09$ & $0.88 \pm 0.08$ \\
19 & $0.86 \pm 0.02$ & $0.66 \pm 0.07$ & $0.80 \pm 0.16$ \\
94 & $0.38 \pm 0.09$ & $0.50 \pm 0.10$ & $0.28 \pm 0.07$ \\
188 & $0.62 \pm 0.18$ & $0.36 \pm 0.10$ & $0.27 \pm 0.0 \%$ \\
750 & $0.21 \pm 0.01$ & $0.39 \pm 0.02$ & $0.24 \pm 0.01$ \\
1880 & $0.17 \pm 0.02$ & $0.30 \pm 0.02$ & $0.23 \pm 0.01$ \\
& & & \\
\hline
\end{tabular}

a) Serosal to mucosal concentration ratio of atenolol. Results represent the mean \pm S.E. $(n \geqq 3)$.

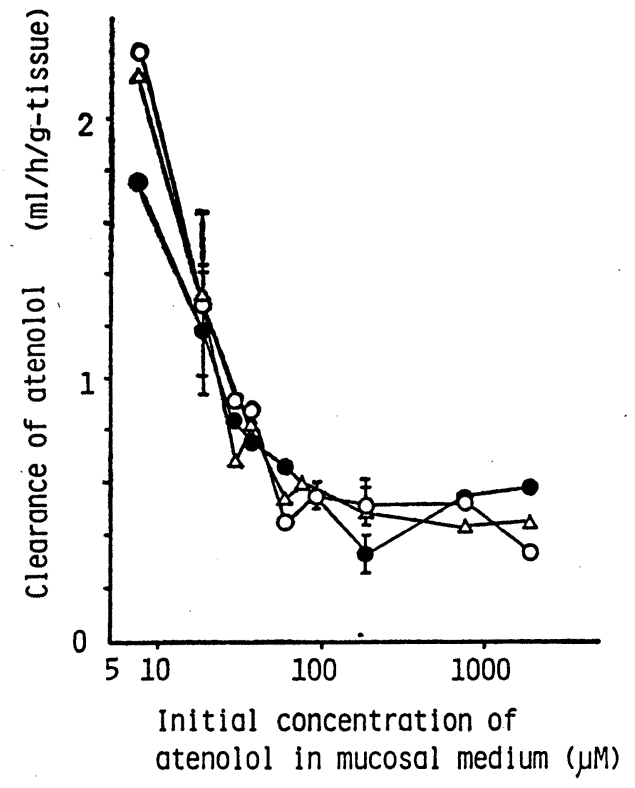

Fig. 6. Effect of Concentrations of Atenolol on Clearance of Drug Transport from the Mucosal Side to the Serosal Side in in vitro Everted Rat Intestinal Sacs Prepared from Segments of Duodenum, Jejunum, and Ileum $\mathrm{O}$ : Duodenum, : jejunum, $\triangle$ : ileum.

Each point represents the mean \pm S.E. $(n>3)$.
吸収過程の, 少なくとも 2 種類の吸収過程が存在するこ とが推測された.したがって高涶度域においては受動 拡散により吸収され，低湦度域においては何らかの carrier-mediate な吸収過程が存在するるのと考光る。 低濃度域における過程は Table 3 において顕著な差が 得られていないこと, Table 4 亿おいて $/ M$ 比が 1 以 下であったことより，エネルギー依存性の能動的輸送で はなく, 膜蛋白と結合することによる促進拡散と推測し ている.しかし，今回の実験においてはその存在を確認 するにたるだけの確証をえていないので，今後さらにそ の吸収機構について検討する予定である.

現在のところ，AT の吸収における消化管内薬物浱度 と吸収率との関係淿ふれた報告はなされていない，Wan ら ${ }^{111}$ はとトに ATを $100,50,25 \mathrm{mg}$ 投与したのち，72 時間にわたって尿中排泄率を測定した結果, その吸収率 は 36.6，40.7，48.0\% であり，投与量の增加とともに 吸収率が減少する傾向を認めたと報告している。したが って，ヒトに扎てて Fig. 6 においてえられたるのと 同様の現象が存在する可能性がある. しかし, Mason ら ${ }^{12)} 100 ， 50 ， 25 \mathrm{mg}$ 投与において，投与量に関係な く50\%の吸収率を示したと報告しており，七トにおける 投与量依存性の存在は明らかではない. 今後, この点に ついても検討を行う必要がある.

䝰辞 アテノロール原末を提供していただいたフィ・ シー・フイファーマ株式会社に深く感碀いたします。 


\section{引用 文 部}

1）大島研三, 池田正男, 金子好宏, 増山善明, 武田 忠直, 梶原長雄, 医学のありみ, 118, 52 (1981).

2）池田正男, 下村克朗, 戸山靖一，加藤和三，早川 弘一, 佐久間昭, 医学のあゆみ, 137, 1031 (1986).

3）挂見喜一郎, 有田隆一, 山科 毦, 小西良士, 薬 剤学, 21, 103 (1961).

4) K. Umeniwa, O. Ogino, K. Miyazaki, T. Arita, Chem. Pharm. Bull., 27, 2177 (1979).

5) D. C. Taylor, R. Grundy, B. Loveday, J. Pharm. Sci., 70, 516 (1981).

6) W.H.Barr, S.Riegelman, J.Pharm. Sci., 59, 154 (1970).
7）アイ・シー・アイファーマ, テノーミン®・イン タビューフォーム.

8) J.D. Fitzgerald, R. Ruffin, K. G. Smedstad, R. Roberts, J. McAinsh, Europ. J. Clin. Pharmacol., 13, 81 (1978).

9）山岡 清, “薬物体内動態解析法”, 南江堂, 東京, 1984, pp. 90-123.

10) D. C. Taylor, R. E. Pownall, W. Burke, J. Pharm. Pharmacol., 37, 280 (1985).

11) S. H. Wan, R.Z. Koda, R.F. Maronde, Brit. J. Clin. Pharmacol., 7, 569 (1979).

12) W.D. Mason, N. Winer, G. Kochak, I. Cohen, R. Vell, Clin. Pharmacol. Ther., 25, 408 (1979). 